\title{
Author Correction: Development and inter-laboratory assessment of droplet digital PCR assays for multiplex quantification of 15 genetically modified soybean lines
}

Alexandra Bogožalec Košir ${ }^{1,2}$, Bjørn Spilsberg ${ }^{3}$, Arne Holst-Jensen ${ }^{3}$, Jana Žel ${ }^{1}$ \& David Dobnik ${ }^{1}$ Correction to: Scientific Reports https://doi.org/10.1038/s41598-017-09377-w, published online 17 August 2017

The Supplementary Information file that accompanies this Article contains an error. In Table S21, for 7-plex MON40-3-2, the sequence “ 5 '-FAM-CCTTTTCCATTTGGG-BHQ- 3 " " should read “ 5 '-FAM-CCTTTTCCATTTGGGMGBNFQ-3"'

(c) (i) Open Access This article is licensed under a Creative Commons Attribution 4.0 International cc. License, which permits use, sharing, adaptation, distribution and reproduction in any medium or format, as long as you give appropriate credit to the original author(s) and the source, provide a link to the Creative Commons license, and indicate if changes were made. The images or other third party material in this article are included in the article's Creative Commons license, unless indicated otherwise in a credit line to the material. If material is not included in the article's Creative Commons license and your intended use is not permitted by statutory regulation or exceeds the permitted use, you will need to obtain permission directly from the copyright holder. To view a copy of this license, visit http://creativecommons.org/licenses/by/4.0/.

(C) The Author(s) 2019

${ }^{1}$ Department of Biotechnology and Systems Biology, National Institute of Biology, Večna pot 111, SI-1000, Ljubljana, Slovenia. ${ }^{2}$ Josef Stefan International Postgraduate School, Jamova 39, SI-1000, Ljubljana, Slovenia. ${ }^{3}$ Norwegian Veterinary Institute, P.O. box 750 Sentrum, 0106, Oslo, Norway. Alexandra Bogožalec Košir and Bjørn Spilsberg contributed equally. Correspondence and requests for materials should be addressed to A.B.K. (email: alexandra. bogozalec@nib.si) 